\title{
Mesenchymal stem cells derived from inflamed dental pulpal and gingival tissue: a potential application for bone formation
}

\author{
Laura Tomasello ${ }^{1,2 \dagger}$, Rodolfo Mauceri ${ }^{3 \dagger}$, Antonina Coppola ${ }^{1,2}$, Maria Pitrone $^{1,2}$, Giuseppe Pizzo ${ }^{3}$, \\ Giuseppina Campisi ${ }^{3}$, Giuseppe Pizzolanti ${ }^{1,2}$ and Carla Giordano ${ }^{1,2^{*}}$
}

\begin{abstract}
Background: Chronic periodontal disease is an infectious disease consisting of prolonged inflammation of the supporting tooth tissue and resulting in bone loss. Guided bone regeneration procedures have become common and safe treatments in dentistry, and in this context dental stem cells would represent the ideal solution as autologous cells. In this study, we verified the ability of dental pulp mesenchymal stem cells (DPSCs) and gingival mesenchymal stem cells (GMSCs) harvested from periodontally affected teeth to produce new mineralized bone tissue in vitro, and compared this to cells from healthy teeth.

Methods: To characterize DPSCs and GMSCs, we assessed colony-forming assay, immunophenotyping, mesenchymal/stem cell phenotyping, stem gene profiling by means of flow cytometry, and quantitative polymerase chain reaction (qPCR). The effects of proinflammatory cytokines on mesenchymal stem cell (MSC) proliferation and differentiation potential were investigated. We also observed participation of several heat shock proteins (HSPs) and actin-depolymerizing factors (ADFs) during osteogenic differentiation.

Results: DPSCs and GMSCs were successfully isolated both from periodontally affected dental tissue and controls. Periodontally affected dental MSCs proliferated faster, and the inflamed environment did not affect MSC marker expressions. The calcium deposition was higher in periodontally affected MSCs than in the control group. Proinflammatory cytokines activate a cytoskeleton remodeling, interacting with HSPs including HSP90 and HSPA9, thioredoxin-1, and ADFs such as as profilin-1, cofilin-1, and vinculin that probably mediate the increased acquisition in the inflamed environment.

Conclusions: Our findings provide evidence that periodontally affected dental tissue (both pulp and gingiva) can be used as a source of MSCs with intact stem cell properties. Moreover, we demonstrated that the osteogenic capability of DPSCs and GMSCs in the test group was not only preserved but increased by the overexpression of several proinflammatory cytokine-dependent chaperones and stress response proteins.
\end{abstract}

Keywords: Inflammation, Dental disease, Pulpal and gingival mesenchymal stem cells, Bone formation, Heat shock protein, ADFs, Proinflammatory cytokines

\footnotetext{
*Correspondence: carla.giordano@unipa.it

${ }^{\dagger}$ Equal contributors

'Laboratory of Regenerative Medicine "Aldo Galluzzo", Department of

Endocrinology, Diabetology and Metabolism, University of Palermo, Piazza

Delle Cliniche 2, 90127 Palermo, Italy

${ }^{2}$ Advanced Technologies Network Center, University of Palermo, Palermo,

Italy

Full list of author information is available at the end of the article
} 


\section{Background}

Chronic periodontal disease is an infectious disease resulting in inflammation within the supporting tissue of the tooth, with progressive attachment and bone loss. It is characterized by pocket formation and/or gingival recession [1]. Some $5 \%$ to $20 \%$ of any population suffers from severe, generalized periodontitis; mild to moderate periodontitis affects a majority of adults and represents the main cause of tooth loss [2]. Along with dental caries, periodontal disease is the main cause of tooth loss; the teeth most commonly lost due to periodontal problems are the first and the second molars in the maxilla [3]. As result of tooth loss, the alveolar process undergoes bone resorption, causing a reduction of the amount of available bone for the insertion of dental implants and the achievement of prosthetic rehabilitation [4, 5].

Guided bone regeneration (GBR) procedures have become a common and safe treatment in dentistry, and autografts are considered the gold standard in GBR procedures for their osteogenic and osteoinductive properties. However, the principal limits are that a donor site is required and only a limited amount of graft is often recoverable [6-8]. For this reason, autologous mesenchymal stem cells (MSCs) would represent the ideal solution for stem cell-based bone tissue engineering.

Tissue engineering (TE) and regenerative medicine (RM) are emerging fields, focused on the development of alternative strategies for tissue or organ repair, that have made significant progress in the last years $[9,10]$. TE provides new regenerated tissues by the appliance of cells, scaffold, and growth factors, alone or in combination; nowadays RM has made exceptional progress leading to the regeneration of numerous organs and organ systems by using the capability of stem cells to differentiate into specialized cell types [11-13].

In adult humans stem cells are hosted in niches, a microenvironment that includes cellular and noncellular components that interact with each other to control the adult stem cells delegated to maintain the integrity of the tissues [14]. MSCs, defined as a population of nonhematopoietic fibroblast-like cells, able to differentiate into multiple lineages, including osteoblasts, adipocytes, and chondrocytes $[9,15]$. During aging, the number of stem cell niches decreases, limiting the possibility of recognizing new sites for the collection of samples and obtaining multiple lines of differentiation for tissue engineering [14, 16, 17].

Over the last years, many niches have been described in the oral cavity: the dental pulp from permanent or deciduous teeth, the periodontal ligament, the apical papilla, the dental follicle, and the gingival tissue [18-22].

Recently, oral MSCs have also been harvested from dental tissue that is not healthy, such as fractured teeth and teeth affected by caries or irreversible pulpitis or aggressive periodontitis [23-26]. Dental pulp MSCs (DPSCs) and gingival MSCs (GMSCs) are clonogenic cells capable of both self-renewal and multiple lines of differentiation; moreover, compared to the bone marrow MSCs (BM-MSCs), DPSCs and GMSCs demonstrate the ability to proliferate faster, to be mostly homogenous, and to have excellent capacity to differentiate into osteogenic cells [18, 27-29]. It is controversial, however, whether proinflammatory cytokines could compromise multipotency and regenerative potential in several types of MSCs in vitro. There is growing evidence that proinflammatory cytokines such as interleukin (IL)-1 $\beta$ or tumor necrosis factor (TNF)- $\alpha$ are important causal factors of cellular proliferation and differentiation in human MSCs [26, 30-33]. Recently, some studies have focused on a possible link between proinflammatory cytokines, bone formation, and various heat shock proteins (HSPs). Inflammation and hypoxic conditions induce the expression of several HSPs engaged in protein folding and actin cytoskeletal organization [34-36]. The actin polymerization remodeling is a fundamental process during lineage-specific differentiation; in this context, Chen et al. showed that the inhibition of main actin depolymerizing factors (ADFs) enhance osteoblastic differentiation in human stromal stem cells [36].

In this study, we evaluated the inflammatory effects on human dental stem cells, particularly DPSCs and GMSCs from inflamed dental tissue, and we investigated if they can be used both as an MSC source and as host tissue in regenerative therapies. We compared the MSC markers, MSC gene profile, proliferation, and in vitro differentiation ability of the DPSCs and GMSCs harvested from periodontally compromised teeth compared to healthy teeth. We investigated if the proinflammatory microenvironment negatively affects dental MSC characteristics and properties, and we speculated about a closer link between chronic inflammation and bone formation through the involvement of several HSPs and ADFs.

\section{Methods \\ Dental pulp and gingival tissue extraction}

Dental pulp was extracted from the teeth of healthy adults aged 18-75 years. The eligibility criteria for participants were as follows: extraction needed for molars suffering from severe periodontal disease (mobility grade III; the test group), extraction needed for wisdom teeth for orthodontic reasons (the control group), no suspect or visibly pregnancy in females, and a positive response to the vitality test performed on teeth to be extracted.

Before the extraction, each patient had to rinse the mouth with $0.2 \%$ chlorhexidin for $1 \mathrm{~min}\left(\mathrm{Meridol}^{\oplus}, \mathrm{Gaba}\right.$ Vebas S.r.l., Rome, Italy) to decontaminate the oral cavity. Gingival tissue was collected while the patient underwent oral surgery procedures for tooth extraction. 
Establishment of dental pulp and gingival cell cultures After surgery, the pulpal or the gingival tissue was transferred in StemLine Mesenchymal Stem Cell Expansion Medium (Sigma-Aldrich, Milano, Italy) enriched with $0.2 \mathrm{mg} / \mathrm{ml}$ gentamicin, $0.25 \mathrm{mg} / \mathrm{ml}$ levofluoxacin, $0.10 \mathrm{mg} / \mathrm{ml}$ vancomicin, and $0.25 \mathrm{mg} / \mathrm{ml}$ fluconazole in a $50-\mathrm{ml}$ tube, and within $24 \mathrm{~h}$ the samples were digested. The digestion was carried out in a solution of $5 \mathrm{mg} / \mathrm{ml}$ collagenase G (Abiel srl, Palermo, Italy) and $2 \mathrm{mg} / \mathrm{ml}$ collagenase $\mathrm{H}$ (Abiel srl, Palermo, Italy) in a 4:1 ratio for $4 \mathrm{~h}$ at $37{ }^{\circ} \mathrm{C}$ under agitation. The digests containing primary cells from the pulp or the gingiva were centrifuged and transferred to a T25 cell culture flask (EuroClone spa, Milano, Italy) or a p60 dish culture (referred to as passage $(\mathrm{P}) 0$ ). The cells were kept in culture in StemLine Mesenchymal Stem Cell Expansion Medium enriched with $0.5 \mu \mathrm{g} / \mathrm{ml}$ gentamicin, $0.25 \mu \mathrm{g} / \mathrm{ml}$ levofluoxacin, $0.10 \mu \mathrm{g} / \mathrm{ml}$ vancomicin, $0.25 \mu \mathrm{g} / \mathrm{ml}$ fluconazole, and $5 \%$ fetal bovine serum (FBS) and incubated at $37{ }^{\circ} \mathrm{C}$ in $5 \%$ $\mathrm{CO}_{2}$. Primary cells attached to the flask in 4-5 days; once they reached $80 \%$ confluence (in about 2 week) they were trypsinized and subculture was started (P1). By subculture P4, the antibiotic and antifungal cover was abolished (expansion medium). P1 to P8 cells were used for the in vitro assays.

\section{Colony-forming assay}

A single-cell suspension (P0) of DPSCs and GMSCs from both the periodontally affected and healthy donors were seeded in a six-well culture in StemLine Mesenchymal Stem Cell Expansion Medium with 10\% FBS at a density of 300 cells/well and cultured at $37{ }^{\circ} \mathrm{C}$ in $5 \%$ $\mathrm{CO}_{2}$. After 14 days, the cells were fixed in $4 \%$ paraformaldehyde and stained with $0.1 \%$ crystal violet. Only the cellular groups containing more than 50 cells were considered as colonies.

\section{Population doubling, cell proliferation curve, and cytokine cytotoxicity}

Proliferation was assayed by trypan blue (Sigma-Aldrich) according to the manufacturer's instructions. The P2 GMSCs or P2 DPSCs from periodontally affected or healthy donors were seeded at a density of $4 \times 10^{3}$ cells/ $\mathrm{cm}^{2}$. The P4 healthy (H)-DPSCs or P4 H-GMSCs with or without $20 \mathrm{ng} / \mathrm{ml} \mathrm{IL}-1 \beta$ and $40 \mathrm{ng} / \mathrm{ml} \mathrm{TNF}-\alpha$ were seeded in a 96-well plate at a density of $4 \times 110^{3}$ cells/ $\mathrm{cm}^{2}$ and cultured up to $120 \mathrm{~h}$. The cell counts were performed by optical microscope observation after trypan blue staining every $24 \mathrm{~h}$ during the incubation period. The doubling time (DT) was calculated accordingly to literature data (http://www.doubling-time.com/compute.php). Three sets of experiments for each sample were used for calculations.

\section{Cytokine toxicity assay}

The P4 H-GDPSCs or P4 H-DGMSCs with or without $20 \mathrm{ng} / \mathrm{ml} \mathrm{IL}-1 \beta$ and $40 \mathrm{ng} / \mathrm{ml} \mathrm{TFN}-\alpha$ were seeded in a 96-well plate at a density of $4 \times 110^{3}$ cells $/ \mathrm{cm}^{2}$ and cultured up to $72 \mathrm{~h}$. The cell viability was evaluated by UV absorption at $550 \mathrm{~nm}$ at 24,48 , and $72 \mathrm{~h}$ using a microplate reader, after 3-(4,5-dimethylthiazol-2-yl)-2,5-diphenyltetrazolium bromide (MTT) incubation for $4 \mathrm{~h}$ at $37{ }^{\circ} \mathrm{C}$. P5 BM-MSCs (Lonza, Walkersville, MD, USA) were used as the positive control.

\section{Flow cytometric analyses \\ Cell cycle cytofluorimetric analysis}

Single-cell suspensions of periodontally affected (P)DPSCs, H-DPSCs, P-GMSCs, and H-GMSCs (P4 culture passages) were obtained and DNA content analysis was performed according to Nicoletti's protocol. Briefly, $1 \times$ $10^{6}$ cells were fixed in $70 \%$ ethanol, rehydrated in phosphate-buffered saline (PBS), and then resuspended in a DNA extraction buffer (with $0.2 \mathrm{M} \mathrm{NaHPO}_{4}$ and $0.1 \%$ Tritonx-100 at $\mathrm{pH} 7.8$ ). After staining with $1 \mu \mathrm{g} / \mathrm{mL}$ propidium iodide for $5 \mathrm{~min}$, fluorescence intensity was determined by analysis on a FACS Calibur flow cytometer (Becton-Dickinson, New Jersey, USA). Data acquisition was performed with CellQuest (Becton Dickinson) software, and the percentages of G1, S, and G2 phase cells were calculated with the MODFIT-LT software program (Verity Software House, Inc.). The proliferation index (PI) was expressed as \% G2 + \% M.

\section{Surface marker cytofluorimetric analysis}

The P-DPSCs, H-DPSCs, P-GMSCs, and H-GMSCs (P4 culture passages) were harvested and filtered through a $40-\mu \mathrm{m}$ filter mesh and suspended at a concentration of $1 \times 110^{6}$ cells $/ \mathrm{ml}$. Then $100 \mu \mathrm{l}$ of cell suspension containing $5 \times 10^{5}$ cells was used for each flow cytometric test.

\section{Immunophenotyping in flow cytometry}

Human anti-HLA-DR, human anti-CD34, and human anti-CD45 monoclonal antibodies were tested on P4 PDPSCs, H-DPSCs, P-GMSCs, and H-GMSCs, and were detected with the appropriate secondary antibody (Table 1). The incubation conditions were in accord with the manufacturer's instructions. Unstained cells were used as the negative control. P4 BM-MSCs used as the positive control are not shown.

\section{Stem cell phenotypes}

The cells were tested for expression of the MSC surface markers Stro-1, CD146, CD29, and SSEA4, with the appropriate human anti-monoclonal antibody (Table 1). The antibody dilution, incubation, and detection conditions are also shown in Table 1. 
Table 1 Human antimonoclonal antibodies used in flow cytometry analysis for detection of mesenchymal stem cell markers

\begin{tabular}{llll}
\hline Antibody, localization marker & Code number & Dilution & \\
\hline $\begin{array}{l}\text { Primary antibodies } \\
\text { Stro-1, surface }\end{array}$ & Thermo Fisher Sc, 39-8401 & $1: 100$ & Incubation \\
CD146, surface & Milteny Biotec, 130-092-851 r.t. \\
CD29, surface & Milteny Biotec, 130-101-258 & $1: 50$ & 30 min, r.t \\
SSEA4, surface & Milteny Biotec, 130-98-371 & $1: 50$ & 30 min, r.t. \\
CD34, surface & Santa Cruz, sc-19621 & $1: 100$ & 30 min, r.t. \\
CD45, surface & Santa Cruz, sc-28369 & $1: 50$ & o/n, r.t. \\
HLA-DR, surface & Santa Cruz, sc-18875 & $1: 50$ & o/n, r.t. \\
Secondary antibody & & $1: 50$ & o/n, r.t. \\
AlexaFluor 488 & Life Technologies, Z25402 & $1: 50$ & 20 min, r.t. \\
AlexaFluor 594 & Life Technologies, Z25007 & $1: 50$ & 20 min, r.t. \\
\hline
\end{tabular}

o/n overnight, r.t. room temperature

All reaction mixtures were then acquired with a FACS Calibur flow cytometer (Becton-Dickinson, New Jersey, USA) and analyzed with the CellQuest Pro software. The specific isotype control antibodies were used as the negative control.

\section{Isolation of total RNA and polymerase chain reaction}

Total RNA was extracted and purified using the E.Z.N.A. Total RNA Kit I (Omega Bio-Tek Inc., GA, USA) according to the manufacturer's instructions. RNA quantity and quality were assessed by Nano Drop 2000 (Thermo Scientific); $2 \mu \mathrm{g}$ limbal fibroblast-like stem cell (f-LSC) total RNA was reverse-transcribed to cDNA in a volume of $20 \mu \mathrm{l}$ with Oligo dT primers (Applied Biosystems, CA, USA) and the Reverse Transcriptase Rnase kit (Improm II, Promega, WI, USA). Real-time quantitative polymerase chain reaction (qPCR) analyses were performed to analyze IL- $1 \beta$ receptor (IL-1 $\beta-\mathrm{R} 1)$ and TNF- $\alpha$ receptor (TNF-R1) expression, the cell proliferation, the stem gene profile, and the osteogenic differentiation, and to detect the expression of the ADFs and HSPs. All reactions were performed using the Quantitect SYBR Green PCR Kit (Qiagen, CA, USA) on the RotorGene Q Instrument (Qiagen). Each cDNA sample was mixed with specific primer sets (listed in Table 2) and PCR master mix. The qPCR reactions were performed using the following parameters for 45 cycles: denaturation at $95{ }^{\circ} \mathrm{C}$ for $3 \mathrm{~min}, 95^{\circ} \mathrm{C}$ for $20 \mathrm{~s}$, annealing at $60{ }^{\circ} \mathrm{C}$ for $30 \mathrm{~s}$, and elongation at $72{ }^{\circ} \mathrm{C}$ for $60 \mathrm{~s}$. Reactions were performed at least in triplicate. The specificity of the amplified products was determined by melting peak analysis. The relative quantification model with efficiency correction was applied to normalize the expression of the target gene to $\beta$-actin (used as the housekeeping gene) and to compare gene expression with BM-MSCs (used as a positive cell control) using the Delta Delta Ct method validated according to the guidelines of Livak and Schmittgen [37]. The results were represented as histograms on GraphPad Software by setting the gene expression of the positive control equal to 1 . The MSCs were used at P5.

\section{The protein-interaction networks (PIN)}

Network analysis was performed on the ADFs, HSPs, and osteogenic proteins using the STRING (Search Tool for the Retrieval of Interacting Genes/Proteins) website (http://string-db.org/). The co-mentions, co-expression and associations in curated databeses were set as the evidence for functional links.

\section{In vitro bone formation}

P-DPSCs, H-DPSCs plus cytokines, H-DPSCs, P-GMSCs, $\mathrm{H}$-GMSCs plus cytokines, and H-GMSCs (all $5 \times 10^{3}$ / $\mathrm{cm}^{2}$ ) were cultured in home-made osteogenic differentiation medium (ODM); $5 \times 10^{3} / \mathrm{cm}^{2} \mathrm{H}$-DPSCs and $\mathrm{H}$ GMSCs were cytokine preconditioned. In detail, H-DPSCs plus cytokines and H-GMSCs plus cytokines were incubated up to $72 \mathrm{~h}$ in expansion medium with $20 \mathrm{ng} / \mathrm{ml} \mathrm{IL-}$ $1 \beta$ and $40 \mathrm{ng} / \mathrm{ml} \mathrm{TNF-} \alpha$ and cultured in ODM. After 21 days of culture in the ODM, cells were stained with Alizarin Red S (Sigma-Aldrich, St. Louis, USA) to detect the calcium deposits. Briefly, the medium was removed and the cells were fixed with $4 \%$ formaldehyde solution for $30 \mathrm{~min}$ and, after fixation, rinsed twice with distilled water and stained with $2 \%$ Alizarin Red S (pH 4.2) for 3 min. After observation under a light optical microscope the images were acquired with a Nikon DS-fil. The quantification of the calcium deposits was assessed by measurement of the optical density (OD) at $550 \mathrm{~nm}$. ODM consisted of Dulbecco's modified Eagle's medium (DMEM) supplemented with 15\% FBS, $10^{-4} \mathrm{mM}$ dexamethasone (Sigma-Aldrich), $10 \mathrm{mM}$ glycerophosphate 
Table 2 The primer sequence list used for the amplification of mesenchymal stem cell cDNA

\begin{tabular}{|c|c|c|}
\hline Gene & Primer sequence & Code number \\
\hline ABCG2 & & QT00073206 \\
\hline CD105 & & QT0001335 \\
\hline THY-1 & & QT00023569 \\
\hline CD73 & & QT00027279 \\
\hline NANOG & & QT01844808 \\
\hline OCT4 & & QT00210840 \\
\hline SOX2 & $\begin{array}{l}\text { F:5'- GGAGACGGAGCTGAAGCCGC-3' } \\
\text { R:5'GACGCGGTCCGGGCTTGTTTT-3' }\end{array}$ & MWG \\
\hline IL-1 $\beta-R 1$ & $\begin{array}{l}\text { F:5'-CCAGGGAACTATTTTTATTTTTCTGG-3' } \\
\text { F:5'-CTGAGAAGCTGGACCCCTTG-3' }\end{array}$ & MWG \\
\hline TNF-R1 & $\begin{array}{l}\text { F:5'-GGGATAAAAGGCAAAGACCAA-3' } \\
\text { F:5'-TCCTTCACCGCTTCAGAAAA-3' }\end{array}$ & MWG \\
\hline ccnd1 & & QT00495285 \\
\hline$c d k n 1 b$ & & QT00998445 \\
\hline c-myc & $\begin{array}{l}\text { F:5'AAACACAAACTTGAACAGCTAC-3' } \\
\text { F:5'-ATTTGAGGCAGTTTACATTATGG-3' }\end{array}$ & MWG \\
\hline runx-2 & $\begin{array}{l}\text { F:5'-TACGACTGGACGCTGGTGC-3' } \\
\text { R:5'-TTCATGGGTCGCTTGACGT-3' }\end{array}$ & MWG \\
\hline opn & F:5'-TGTGGGTTTCAGCACTCTGGTCA-3', R:5'-AAGCGAGTTGAATGGTGC-3' & MWG \\
\hline ocn & $\begin{array}{l}\text { F:5'-CTGACCTCACAGATGCCAAG-3' } \\
\text { R:5'-GTAGCGCCGGAGTCTGTTC -3' }\end{array}$ & \\
\hline CFL-1 (cofilin) & $\begin{array}{l}\text { F:5'-TGCGGCTCCTACTAAACGG-3' } \\
\text { F:5'-ACGCACCTTCATGTCGTTGA-3' }\end{array}$ & MWG \\
\hline PFN-1 (profilin) & $\begin{array}{l}\text { F:5'-ACCCGGAAACAAGAAGAC-3' } \\
\text { F:5'-ACTGGTCCGATAACCTCCCA-3' }\end{array}$ & MWG \\
\hline VCL (vinculin) & $\begin{array}{l}\text { F:5'-ATGTCTCCTATATCCTGGTTT-3' } \\
\text { F:5'-GCAGGAAGTGTCCTTCAGAC-3' }\end{array}$ & MWG \\
\hline HSPA9 (mortalin) & $\begin{array}{l}\text { F:5'-TACAGCAGATGGTGAGCGAC-3' } \\
\text { R:5'-TGCTGTGTGCCCCAAGTAAT-3' }\end{array}$ & MWG \\
\hline TXN-1 (thioredoxin-1) & $\begin{array}{l}\text { F:5'- GTGAAGTCAAATGCACGCCA-3' } \\
\text { R:5'-GCAGATGGCAACTGGTTATGT-3' }\end{array}$ & MWG \\
\hline HSP90AA1 & $\begin{array}{l}\text { F:5'-GTGAAGTCAAATGCACGCCA-3' } \\
\text { R:5'-GCAGATGGCAACTGGTTATGT-3' }\end{array}$ & MWG \\
\hline
\end{tabular}

$F$ forward, $R$ reverse

(Sigma-Aldrich), and $0.05 \mathrm{mM}$ ascorbic acid (SigmaAldrich) [9]. P6 MSCs were used for in vitro bone formation assay.

\section{Statistical analysis}

All assays were performed in triplicate. The data are reported as means \pm SD and compared using the appropriate version of the Student's unpaired $t$ test or one-way analysis of variance and post Tukey's multiple comparison test. $p<0.05$ was considered statistically significant.

\section{Results}

Inflamed dental tissue-derived MSCs show a higher proliferative ability

DPSCs and GMSCs were isolated from 49 patients. The subjects were divided into two major groups: 1) the periodontally affected group (P, the test group; $n=37$ ); and 2) the healthy group ( $\mathrm{H}$, the control group; $n=12)$. For each patient, pulpal and gingival tissues were extracted. Nine of the total samples ( $n=5$ test group; $n=4$ control group) were unsuccessfully processed with high grades of bacterial contamination. For all 40 remaining samples, a cell suspension was generated after enzymatic digestion. The first plastic adherent cells were detected from all cultures between 7 and 10 days after preparation, and primary cells from healthy tissue initially grew much faster than those from periodontally affected tissue. The cultures (P0) appeared heterogeneous in shape and size, and the cells showed the ability to grow out from tissue now totally digested and to form clone-like growth (Fig. 1a). Generally, as culture progressed, gingival cells reached confluence at day 15 (12-18 days) 


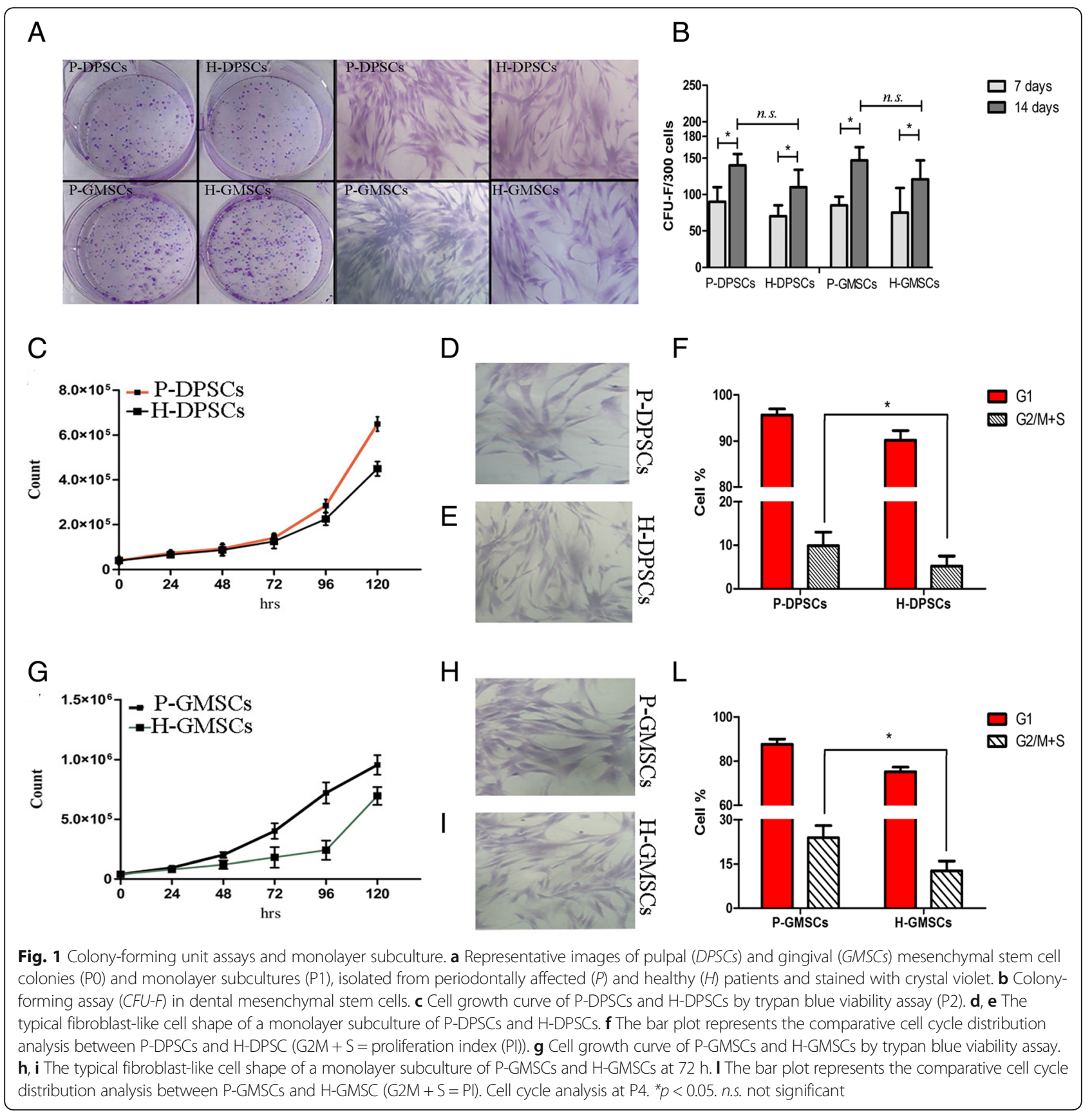

and pulpal cells at day 20 (14-26). All the primary cells showed a typical fibroblast-like morphology, and they were homogeneous in shape and size (Fig. 1a). The CFU-F assay is the most frequently used test to analyze the clonogenic potential of isolated MSCs and to demonstrate MSC enrichment. Thus, we performed a CFU-F assay on all dental MSCs; P-DPSCs, H-DPSCs, PGMSCs, and H-GMSCs displayed the highest timedependent colony-forming ability, and a significant enrichment was observed in periodontally affected dental MSCs with respect to their healthy controls. Based on counting, the number of colonies per 300 seeded cells was $90.4 \pm 18.07$ and $140.2 \pm 15.8(p<0.05)$ for the P-DPSCs at 7 and 14 days, respectively, and $88.3 \pm 12.03$ and $146.8 \pm 28.8(p<0.05)$ for the P-GMSCs at 7 and 14 days, respectively; the results were $75.1 \pm 15.05$ and $121.2 \pm 23.6(p<0.05)$ for the H-DPSCs at 7 and 14 days, respectively, and $70.3 \pm 28.03$ and $111.03 \pm 24.8(p<0.05)$ for the H-GMSCs at 7 and 14 days, respectively (Fig. 1b). After they reached confluence, the cells were harvested and subcultured. From culture P1, a modest change in growth behavior was observed; in spite of the MTT assay 
revealing no significant difference $(p>0.05)$ in the growth rate (Additional file 1), the P-DPSCs and PGMSCs proliferated faster than healthy control cells. DT was established at $28.83 \pm 2 \mathrm{~h}$ vs. $34.37 \pm 5 \mathrm{~h}$ for PDPSCs vs. H-DPSCs, respectively, and at $26.22 \pm 8 \mathrm{~h}$ vs. $29.13 \pm 4 \mathrm{~h}$ for P-GMSCs vs. H-GMSCs, respectively (Fig. 1c and g; Additional file 1). The cell cycle analysis assigned a proliferation index (PI) G2M $+\mathrm{S}$ of $9.90 \pm 3.1 \%$ vs. $5.23 \pm 2.3 \%$, respectively, in P-DPSCs vs. H-DPSCs and a PI of $23.85 \pm 4.1 \%$ vs. $12.72 \pm 3.24 \%$, respectively, in PGMSCs vs. H-GMSCs (Fig. If and l; Additional file 1). The difference in PI between P-DPSCs and H-DPSCs and between P-GMSCs and H-GMSCs was statistically significant $(p<0.005)$.

Human healthy and periodontally affected gingival and pulpal dental cells express putative mesenchymal stem cell markers, are negative for hematopoietic

differentiation clusters, and represent a stem gene profile The isolated cells did not display any hematopoietic surface markers (CD34 and CD45) and HLA-DR. Some increases were detected in the expression levels of CD34 in periodontally affected samples; however, this was not statistically significant $(p>0.005)$ (Fig. 2$)$. The expression of putative the mesenchymal surface stem cells markers Stro-1, CD146, CD29, and SSEA4 was observed by flow cytometry and compared to BM-MSCs (data not shown) (Fig. 3). A higher Stro- $1^{+} / \mathrm{CD} 146^{+} / \mathrm{SSEA}-4^{+}$cell population $(p<0.05)$ in P-DPSCs and P-GMSCs with respect to their healthy controls was detected. In all samples, CD29 stayed highly positive (about 100\%). The expression values are reported in Additional file 2.

We compared the stem cell molecular expression pattern in the P-DPSCs, P-GMSCs, H-DPSCs, and HGMSCs as differences in fold change. Generally, we found a higher expression of all stem markers in dental mesenchymal stem cells with respect to the BM-MSCs (used as positive control; value of relative gene expression $=1$ ). In detail, the mRNA levels of the embryonic stem cell markers NANOG and OCT4 showed very high fold change with respect to BM-MSCs. Moreover, the expression levels of the main stemness genes were significant higher in periodontally affected MSCs compared to their healthy controls whereas, a lower mRNA level

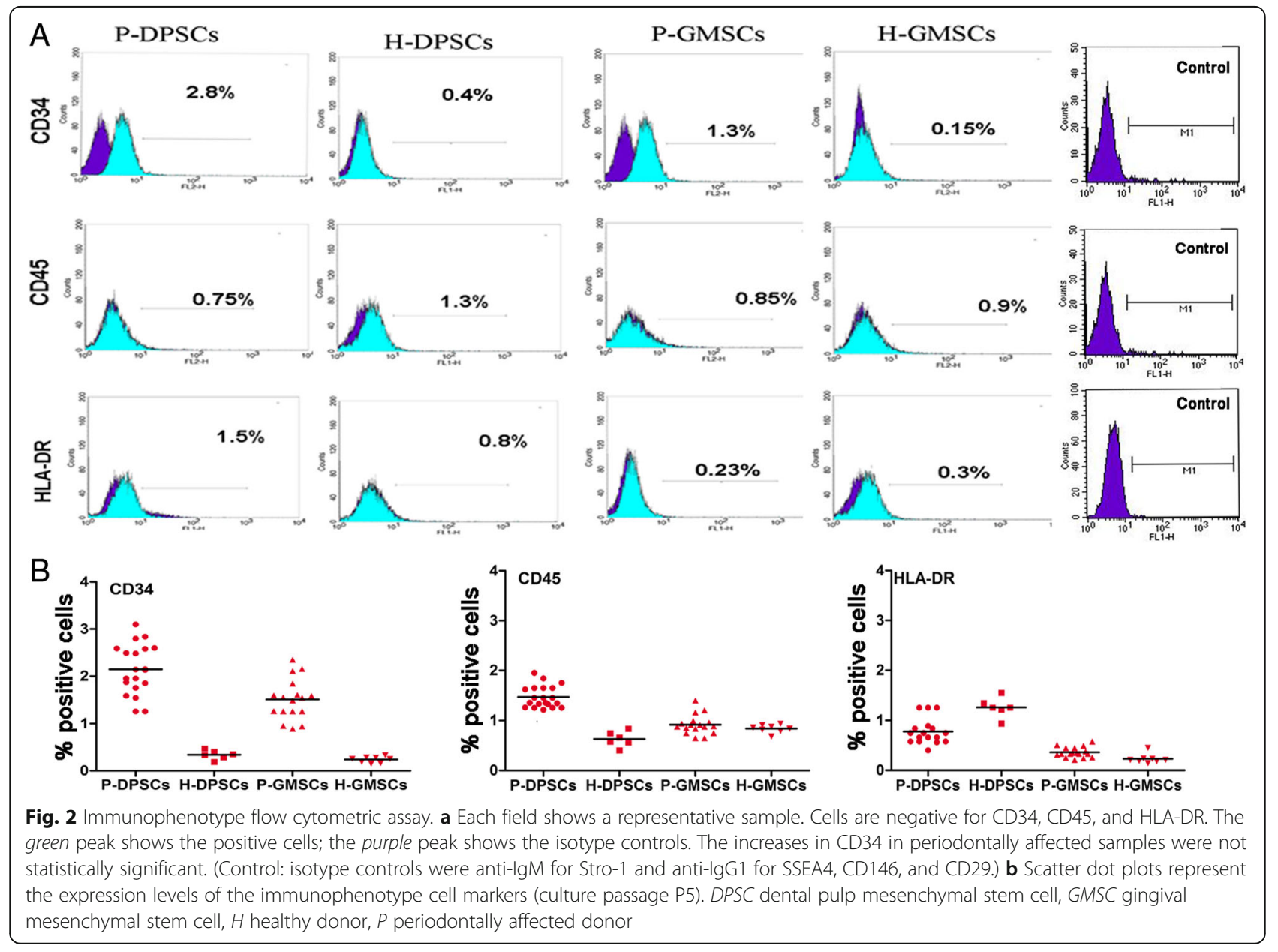




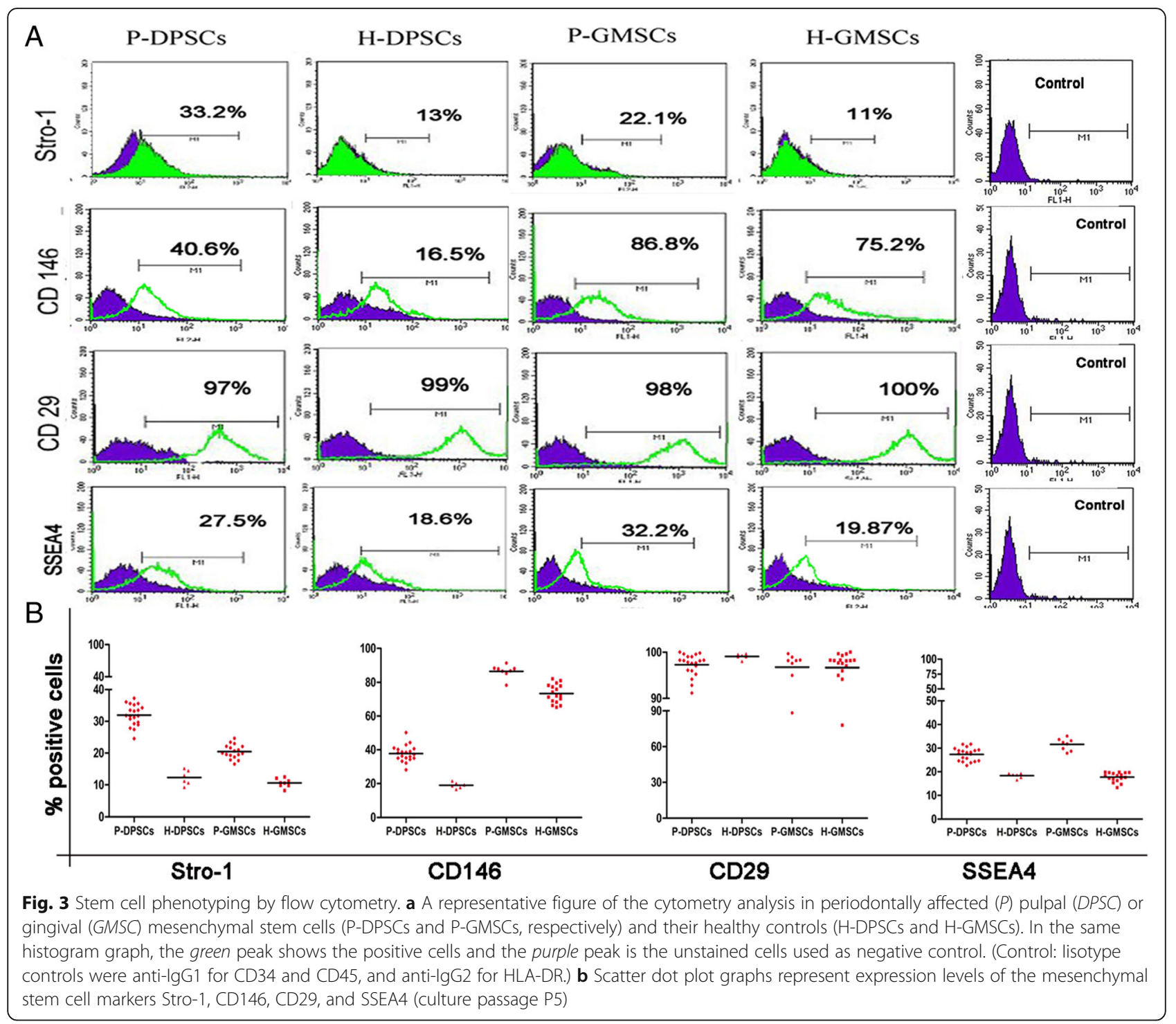

of the CD73 surface marker was found in periodontally affected MSCs compared to their healthy control $(p<0.05$; Fig. 4).

The proinflammatory cytokine cocktail facilitates pulpal and gingival mesenchymal stem cell expansion in vitro We investigated the effect of the proinflammatory cytokines IL- $1 \beta$ and TNF- $\alpha$. Firstly, we confirmed the presence of IL-1 $\beta$ and TNF- $\alpha$ receptors in P-GMSCs and P-DPSCs and their healthy controls, in basal and under cytokine treatment conditions (Additional file 3). After $72 \mathrm{~h}$ of treatment no cytotoxic effect on cells was found; we even found a proliferation advantage acquisition. Indeed, a decrease in DT was detected in $\mathrm{H}$ DPSCs and H-GMSCs treated with IL- $1 \beta$ and TNF- $\alpha$, mimicking the P-DPSC and P-GMSC proliferation curve (Fig. 5a), and the MTT analysis showed an increase in the percentage of vital cells (Fig. 5b). We evaluated the principal molecules involved in cell proliferation. The qPCR analysis for c-myc (myc-protoncogene), ccnd1 (cyclin-D1), and cdkn1b (cyclin-dependent kinase inhibitor 1B) was assessed for each time point of culture in H-DPSCs and H-GMSCs treated with IL-1 $\beta$ and TNF- $\alpha$ versus untreated healthy controls. In line with the MTT results we found a significant upregulation of c-myc and ccnd1 in dental MSCs (Fig. 5c, middle and lower panels). Consistent with the above results, we found a downregulation of the ccnd1 inhibitor (cdkn1b). In addition, as a consequence of the cytokine treatment, the same genes were found to be modulated with the opposite trend in BM-MSCs (in Fig. 5c, upper panel). 

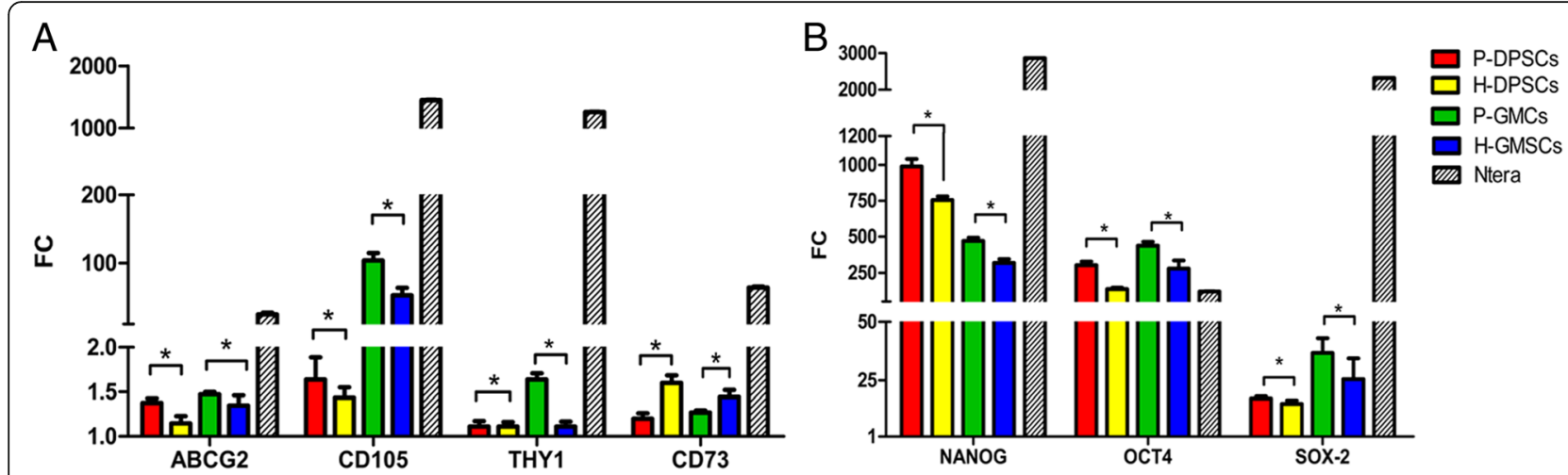

Fig. 4 Stem cell gene expression profile of dental periodontally affected $(P)$ and healthy $(H)$ mesenchymal stem cells (MSCS) from dental pulp (D) and gingival $(G)$ tissues. a Comparative analysis of surface marker expression in P-DPSCs, H-DPSCs, P-GMSCs, and H-GMSCs. b Comparative analysis of nuclear surface marker expression in P-DPSCs, H-DPSCs, P-GMSCs, and H-GMSCs. Mean values \pm SD of all samples studied are reported. Actin $\beta$ was used as the housekeeping gene. mRNA expression of all analyzed genes was normalized against BM-MSCs (positive control, relative gene expression value $=1$ ). Culture passage P5. ${ }^{*} p<0.05$; Ntera is used as internal control. FC fold change

\section{Inflammation and stem cell gene profile correlation}

To investigate whether the inflammation environment affects stem cell gene profile, a qPCR analysis was performed to compare H-GMSCs and H-DPSCs after $20 \mathrm{ng} / \mathrm{ml} \mathrm{IL-1} \beta$ and $40 \mathrm{ng} / \mathrm{ml} \mathrm{TNF- \alpha}$ up to $72 \mathrm{~h}$ versus untreated HGMSCs and H-DPSCs. In Fig. 5d the histograms represent the mRNA levels expressed as fold change. In cytokinetreated H-GMSCs and H-DPSCs all MSC markers showed an increase with respect to H-GMSCs and H-DPSCs $(p<$ 0.05), except for CD105 in H-DPSCs after the treatment ( $\mathrm{p}>0.05)$ and CD73 which showed a decrease $(p<0.05)$.

We found increases of about 1.06- and 1.07-fold in ABCG2 $(p<0.05), 1.06=$ and 1.37-fold in CD105 $(p>0.05$ and $p<0.05), 1.08$ - and 1.33-fold in THY-1 $(p<0.05)$, 1.15 - and 1.76-fold in NANOG $(p<0.05), 1.77$ - and 1.14fold in OCT4 $(p<0.05)$, and 2.89- and 1.83-fold in SOX-2 $(p<0.05)$ in H-DPSCs plus cytokines vs H-DPSCs and HGMSCs plus cytokines vs H-DPSCs, respectively.

\section{In vitro bone formation: inflammation, cytoskeleton modulation, and osteogenesis}

To evaluate the effect of the inflammatory conditions on the osteogenic differentiation potential in vitro, $\mathrm{H}$ DPSCs and H-GMSCs were treated with IL-1 $\beta$ and TNF- $\alpha$ up to $72 \mathrm{~h}$ and then they were cultivated in ODM. After 15 days of the differentiation culture procedure, phenotypic and gene analyses were performed to compare treated healthy cells and periodontally affected cells with untreated healthy dental MSCs. Using phasecontrast microscopy the Alizarin Red S staining was evaluated, and we observed that treated MSCs and periodontally affected MSCs appeared more stained than untreated healthy controls (Fig. 6a). Confirming these observations, the Alizarin Red $S$ absorbance was measured at $550 \mathrm{~nm}$ (Fig. 6b). We found a relative OD increase of about 1.05 and 1.31 in treated H-DPSCs and P-DPSCs, and of about 1.41 and 1.67 in treated $\mathrm{H}$ GMSCs and P-GMSCs compared to their healthy controls. Moreover, the early osteogenic marker runx-2 was found to be upregulated by 1.41-fold and 1.38-fold, respectively, in P-DPSCs and P-GMSCs $(p<0.05)$ compared to their healthy controls; the difference between treated and untreated MSCs was not significant $(p>0.05)$. However, treated MSCs and periodontally affected MSCs showed significantly higher mRNA levels of the later osteogenic differentiation markers compared to their untreated healthy controls. Specifically, we detected an upregulation in osteopontin levels of 2.09-fold and 2.18-fold in treated H-DPSCs and P-DPSCs and 1.42-fold and 1.71-fold in treated H-GMSCs and PGMSCs $(p<0.05)$, and upregulation of osteocalcin levels of 1.14-fold and 1.15-fold in treated H-DPSCs and PDPSCs and 1.25-fold and 1.27-fold in treated H-GMSCs and P-GMSCs $(p<0.05)$ (Fig. 6b).

\section{IL-1 $\beta$ and TNF- $\alpha$ increase the expression of several ADFs and HSPs}

A computational STRING analysis was performed to investigate the functional interaction between osteogenic differentiation, actin cytoskeletal organization, and cytokine response. The chief members of each protein cluster analyzed were the following: runx-2, opn, ocn (osteogenic differentiation markers), cofilin-1 and profiling-1 (ADFs), vinculin (the key depolymerization factor), and hsp90, hspA9, and txn-1 (the main heat shock proteins). Based on the criteria set, we obtained a network of proteinprotein interactions (PPI) that linked together all three protein clusters (Fig. 7a). After 15 days of osteoblastic differentiation, qPCR analysis was assessed to test the mRNA levels of ADFs and HSPs. Generally, the cytokine-treated 


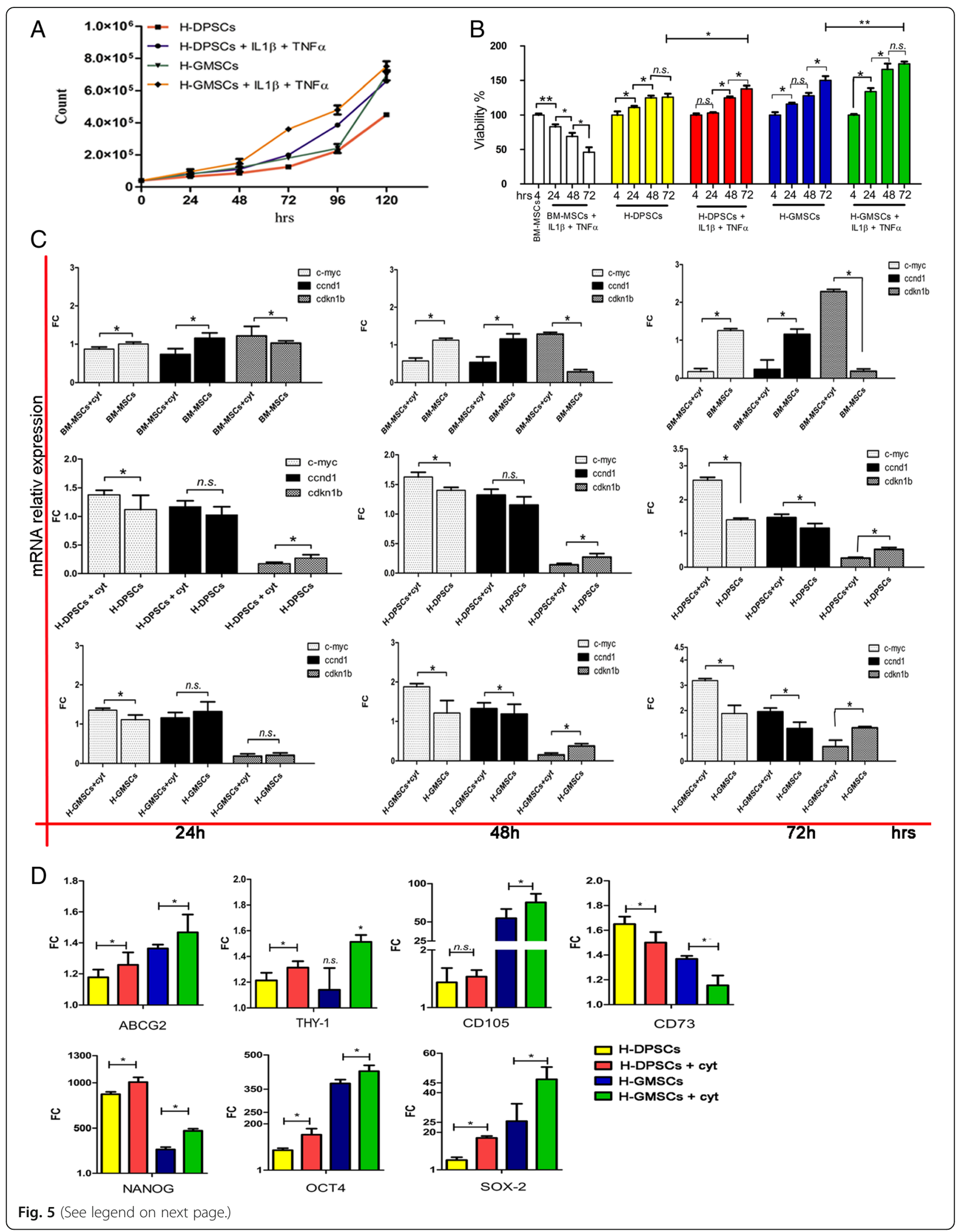


(See figure on previous page.)

Fig. 5 Two cytokines promote H-GMSC and H-DPSC expansion. a Cell growth curve of healthy dental pulp mesenchymal stem cells (H-DPSCS) and healthy gingival MSCs (H-GMSCS) with and without cytokines (cyt; $20 \mathrm{ng} / \mathrm{ml}$ interleukin-1 beta (IL1 $\beta$ ) and $40 \mathrm{ng} / \mathrm{ml}$ tumor necrosis factor alpha (TNFa) for $72 \mathrm{~h}$ ) by trypan blue viability assay. $\mathbf{b}$ Cytotoxicity assay: H-DPSCs and H-GMSCs without and after cytokine treatment. c qPCR analysis of cell cycle regulators and proliferation markers ccnd1, cdnk1 b, and c-myc in H-DPSCs + cyt and H-GMSCs + cyt and their healthy controls at 24, 48, and $72 \mathrm{~h}$. d Comparative analysis of nuclear and surface marker expression in H-DPSCs + cyt and H-GMSCs + cyt and their healthy controls at $72 \mathrm{~h}$. Bone marrow MSCs (BM-MSCs) used as positive control (relative gene expression value $=1$ ); $\beta$-actin is the housekeeping gene. Mean values $\pm S D$ of all samples studied are reported. SD bars are based on three independent experiments. Culture passage P5. ${ }^{*} p<0.05$. FC fold change, n.s. not significant
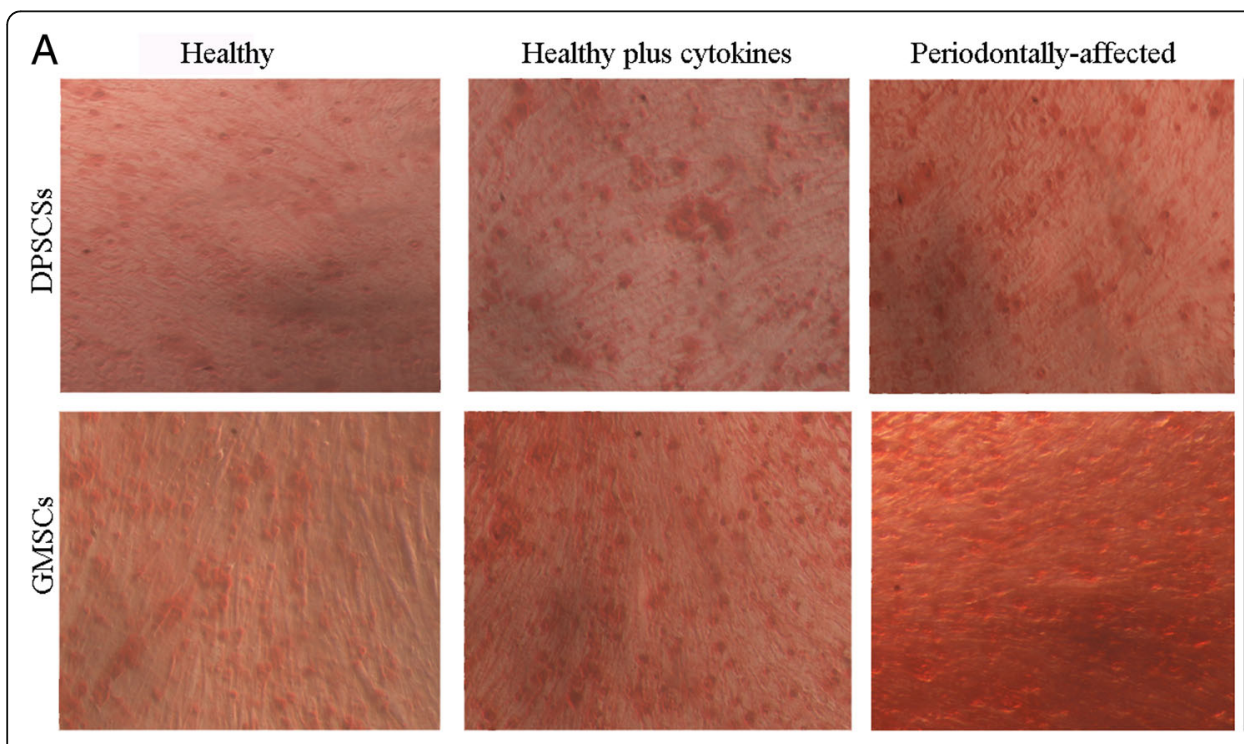

CONTROL
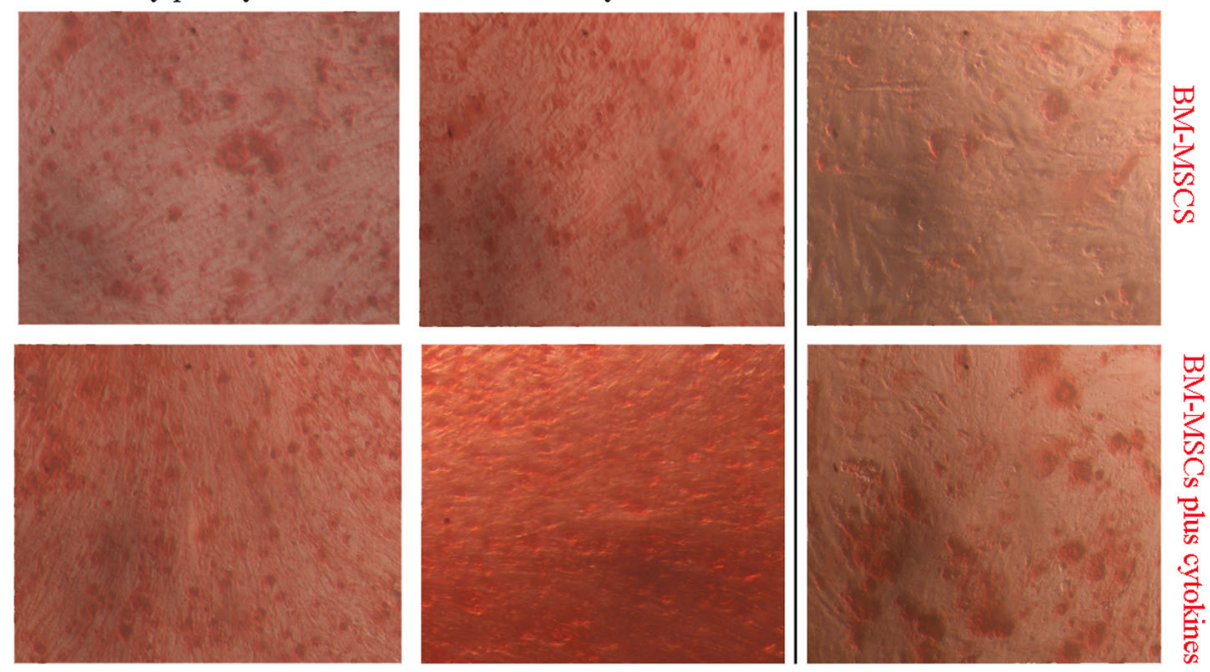

B

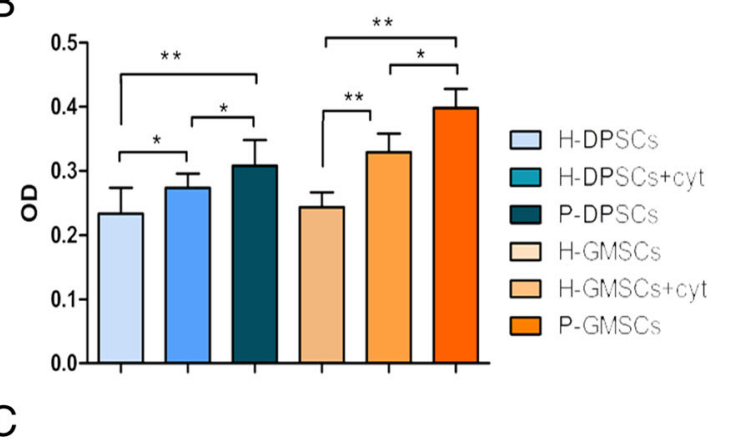

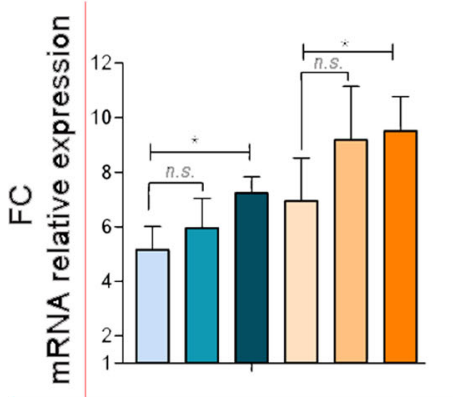

runx-2

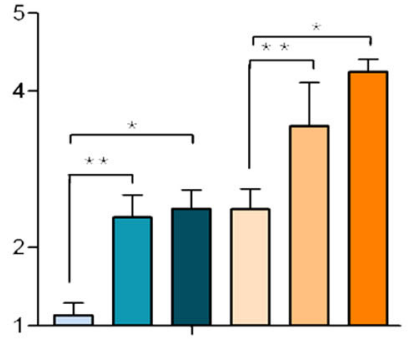

opn

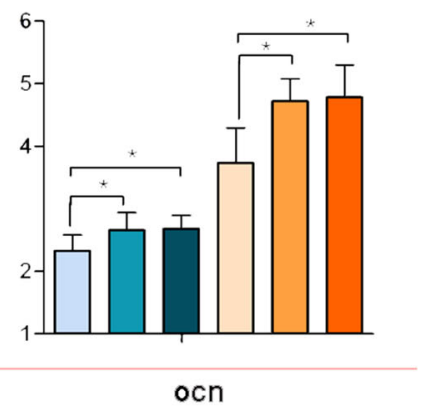

$\square \mathrm{H}-\mathrm{DPSCS}$

$\square$ H-DPSCs+cyt

$\square$ P-DPSCS

$\square$ H-GMSCS

$\square$ H-GMSCS+Cyt

$\square$ P-GMSCS

Fig. 6 The osteogenic potential of pulpal (DMSCS) and gingival (GMSCs) mesenchymal stem cells. a A representative image of Alizarin Red assay stained calcium deposits after 15 days of osteogenic differentiation cultured in healthy (H)-DPSCs and H-GMSCs with or without cytokine (cyt) preconditioning, and periodontally affected (P)-DPSCs, P-GMSCs, and bone marrow MSCS (BM-MSCS) with or without cytokine preconditioning (control). $\mathbf{b}$ The bar graph represents the quantitative analysis of Alizarin by means of spectrometry (reading at $550 \mathrm{OD}$ ). $\mathbf{c}$ the bar graphs represent the relative mRNA expression of early and later osteogenic differentiation markers. Culture passage P5. ${ }^{*} p<0.05 ;{ }^{* *} p<0.01$. FC fold change, n.s. not significant 

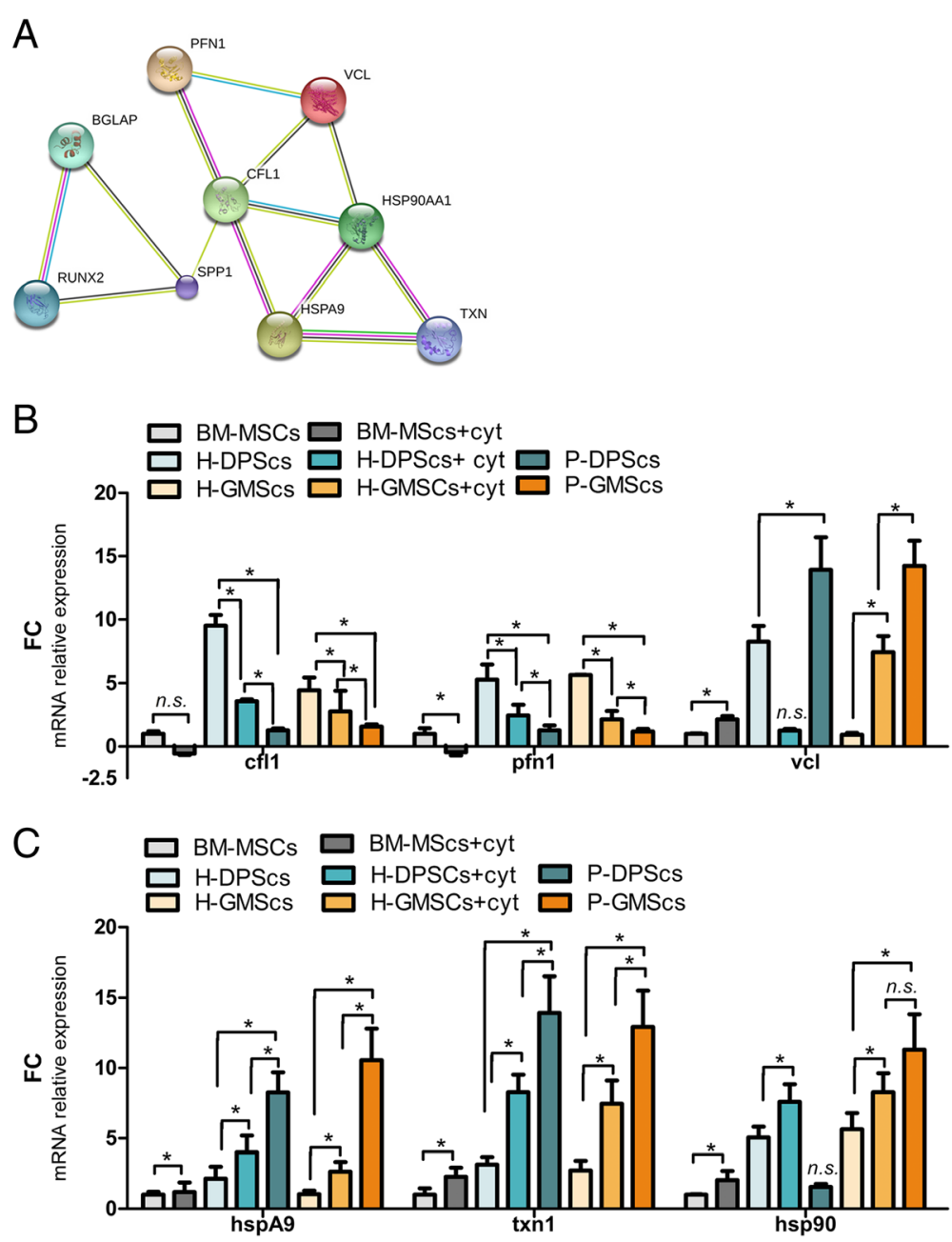

Fig. $7 \mathrm{LL}-1 \beta$ and TNF- $\alpha$ increase the expression of several ADFs and HSPs. a The interaction between cytoskeleton-regulating proteins, antiinflammatory chaperone proteins, and the osteogenic specific markers performed at http://string-db.org/. b, c The bar graphs represent the qPCR analysis for $\mathbf{b}$ ADF gene and $\mathbf{c}$ heat shock protein gene in bone marrow mesenchymal stem cells (BM-MSCs), BM-MSCs + cytokines (cyt; $20 \mathrm{ng} / \mathrm{ml}$ IL1 $\beta+40 \mathrm{ng} / \mathrm{ml}$ TNFa), healthy (H) dental pulp MSCs (DPSCs), H-DPSCs + cyt, periodontally affected (P)-DPSCs, healthy gingival MSCs (H-GMSCs), HGMSCs + cyt, and P-GMSCs. Mean values \pm SD of all samples studied are reported. SD bars are based on three independent experiments. Culture passage P6. ${ }^{*} p<0.05$. FC fold change, n.s. not significant

and periodontally affected MSCs expressed lower mRNA levels of ADFs and higher mRNA levels of HSPs. Specifically, ADF downregulation and vinculin upregulation were found in cytokine-treated and periodontally affected MSCs $(p<0.05)$ with respect to untreated healthy controls (Fig. 7b). Moreover, upper levels of about 2.5- and 5-fold were found in hsp90, hspA9, and txn-1 expression in cytokine-treated and periodontally affected MSCs compared to untreated healthy controls (Fig. 7c).

\section{Discussion}

For decades, extraordinary interest has emerged in the field of MSCs because of their differentiation potential that introduces them for possible use in TE, RM, and cell and gene therapy for clinical applications. Scientists are ongoing in their search for the best source of MSC tissue. The current elective tissues to this end are bone marrow and adipose tissue, although the isolation of these MSCs is an invasive procedure for both patients and donors. In view of this, the possibility to isolate MSCs from discarded tissue is a fascinating idea and MSCs from periodontally affected patients could be a good alternative. Even though it has been shown in the literature that proinflammatory cytokines affect the MSC properties, the effects of inflammation due to periodontitis and its effects on the features of dental MSCs remain unclear [26, 30, 31].

In the present study, we confirmed the presence of MSCs in human dental pulp and gingival tissue harvested from periodontally affected patients and for the first time, to best of our knowledge, we compared their stem features to DPSCs and GMSCs harvested from 
healthy donors at the same time. The cells isolated from all groups showed a typical fibroblast-like shape and displayed positivity for the principle stem markers Stro1, CD46, CD29, and SSEA4, and they did not display surface expression for any hematopoietic marker (CD34 and CD45). Our results suggested that the inflamed condition relating to the periodontal status of the patients had no effect on dental MSC viability, whereas it could improve the growth ability and stem cell gene profile of DPSCs and GMSCs. This view was supported by proinflammatory cytokine preconditioning experiments that demonstrated that H-DPSCs and H-GMSCs are able to mimic P-DPSCs and P-GMSCs, displaying similar proliferation curves and gene expressions when treated with IL-1 $\beta$ and TNF- $\alpha[31,32]$. Specifically, PDPSCs and P-GMSCs showed a clear, higher expression of the cardinal stem nuclear markers NANOG, OCT4, and SOX-2, and stem superficial markers ABCG2, CD105, and THY-1, compared to healthy controls and the internal positive control (BM-MSCs). Moreover, our data on H-DPSCs and H-GMSCs under proinflammatory conditions in vitro showed that osteoblastic differentiation capacity is not only well preserved but also is significantly higher than under nonstimulated conditions, and almost equal to periodontally affected MSCs. This evidence was confirmed by a higher calcified extracellular matrix formation and a higher expression of early and later osteogenic differentiation markers (runx2, osteopontin, and osteocalcin) in the cytokinetreated H-DPSCs and H-GMSCs as well as in the periodontally affected MSCs [38-40].

It has already been shown that, in inflammatory environments, several mediators activate a set of biological process such as cell survival, proliferation, and cell differentiation in MSCs [41-46]. During lineage-specific differentiation, human stromal stem cells exhibit significant changes in morphology. The differentiation process is closely linked to the remodeling of the actin cytoskeletal organization by means of the collaboration between the actin depolymerizing factors and chaperone proteins [47-51]. In the first instance, the ADFs bind to actin monomers and filaments, causing depolymerization of actin filaments preventing their reassembly and hindering differentiation [52-55]. In the second instance, chaperone/HSP proteins, including hsp90, hspA9, and thioredoxin, assist the main ADFs (cofilin, profiling, and vinculin) to model actin polymerization status [33-36, 56, 57].

Our in vitro data suggested that the chronically inflamed environment, perpetuated by persistent proinflammatory cytokines, could be an advantage for the human P-DPSCs and P-GMSCs. This inflammatory background maintains high expression levels of hsp90, txn-1, and hspA9 that finally allows the stabilization of actin filaments by means vinculin, profilin-1, and cofilin-1.

\section{Conclusions}

Our results confirm that the chronic inflammatory microenvironment that exists in periodontitis does not negatively affect the number or the stem cell marker profile of P-DPSCs and P-GMSCs. The proinflammatory cytokines permit a higher osteogenic differentiation potential, controlling MSC fate through several regulatory mechanisms involving remodeling of the cytoskeleton and stress response process. This convinces us that periodontally affected MSCs are a valid autologous MSC source and that they could be employed for in vivo applications in diseases with a persistent inflammatory environment that generally harms the features and hinders the success of cell transplantation. From a clinical point of view, these findings are promising for future tissue engineering applications in vivo.

\section{Additional files}

\begin{abstract}
Additional file 1: Figure S1. A) Bar graph represents the MTT absorbance mean values \pm SD of P-DPSCs and P-GMSCs vs. their healthy control. The differences were not significant. B) The histograms represent the comparison of DT. Mean values \pm SD are based on three independent experiments. $n . s=$ not significant ( $p$ value $>0.05$ ). C) Each field shows a cell cycle analysis representative of each sample investigated. (TIF $11728 \mathrm{~kb}$ )

Additional file 2: Table S1. The expression values of putative mesenchymal surface stem cells markers. (DOC $31 \mathrm{~kb}$ )

Additional file 3: Figure S2. A, B) Basal gene expression of $I L-1 \beta$ and TNF-a receptors in P-DPSCs, H-DPSCs, P-GMSCs, and H-GMSCs. C, D) Gene expression of IL-1 $\beta$ and TNF-a receptors under cytokine stimulation at 24 , 48, and 72 h (cytokine treatment: 20 ng/ml IL-1 $\beta+40$ ng/ml TNF-a). * $p$ value $<0.05 ;$ n.s = not significant. $F C=$ fold change. (JPG $239 \mathrm{~kb})$
\end{abstract}

\section{Abbreviations}

ABCG2: ATP-binding cassette sub-family G member 2; ADF: Actin depolymerizing factor; BM-MSC: Bone marrow mesenchymal stem cell; CD: Cluster differentiation; Cfl-1: Cofilin-1; DPSC: Dental pulp mesenchymal stem cell; DT: Doubling time; FBS: Fetal bovine serum; f-LSC: Limbal fibroblast-like stem cell; GBR: Guided bone regeneration; GMSC: Gingival mesenchymal stem cell; HSP: Heat shock protein; IL: Interleukin; MSC: Mesenchymal stem cell; NANOG: Homeobox protein NANOG; OCT4: Octamer-binding transcription factor 4; OD: Optical density; ODM: Osteogenic differentiation medium; opn: Osteopontin; P: Passage; PI: Proliferation index; Pfn-1: Profilin-1; qPCR: Quantitative polymerase chain reaction; RM: Regenerative medicine; runx-2: Runt-related transcription factor 2; SOX-2: SRY (sex determining region Y)-box 2; SSEA-4: Stage-specific embryonic antigen-4; STRING: Search Tool for the Retrieval of Interacting Genes/Proteins; TE: Tissue engineering; THY-1: Thy-1 cell surface antigen; TNF: Tumor necrosis factor; Vcl: Vinculin

\section{Funding}

None.

Availability of data and materials

The authors declare that all relevant data are included in the article and its supplementary information files.

\section{Authors' contributions}

LT and RM: conception and design, collection and assembly of data, data analysis and interpretation, manuscript writing; GP, MP, AC, and GP: collection and assembly of data; GC and CG: conception and design, provision of study material or patients; LT: data analysis and interpretation; GP: acquisition of data; LT and RM: manuscript writing; CG: conception and design, data analysis and interpretation, manuscript writing and final 
approval of manuscript, manuscript drafting and revising critically for important intellectual content financial support. All authors read and approved the manuscript.

\section{Ethics approval and consent to participate}

All the procedures reported were approved by the Internal Ethical Committee of the University Hospital A.U.O.P "P. Giaccone" of Palermo. Patients signed an informed consent form before being recruited to the study. The study was approved by the Comitato Etico Palermo 1, record number N5/2014, with the following title: "Ricerche in vitro ed ex vivo su cellule staminali di origine pulpare e di origine gengivale da elementi dentari parodontopatici".

\section{Consent for publication}

Not applicable.

\section{Competing interests}

The authors declare that they have no competing interests.

\section{Publisher's Note}

Springer Nature remains neutral with regard to jurisdictional claims in published maps and institutional affiliations.

\section{Author details}

'Laboratory of Regenerative Medicine "Aldo Galluzzo", Department of Endocrinology, Diabetology and Metabolism, University of Palermo, Piazza Delle Cliniche 2, 90127 Palermo, Italy. ${ }^{2}$ Advanced Technologies Network Center, University of Palermo, Palermo, Italy. ${ }^{3}$ Department of Surgical, Oncological and Oral Sciences, University of Palermo, Palermo, Italy.

\section{Received: 4 January 2017 Revised: 26 June 2017}

\section{Accepted: 14 July 2017 Published online: 01 August 2017}

\section{References}

1. Highfield J. Diagnosis and classification of periodontal disease. Aust Dent J. 2009:54 Suppl 1:S11-26.

2. Burt B. Research, Science and Therapy Committee of the American Academy of Periodontology. Position paper: epidemiology of periodontal diseases. J Periodontol. 2005;76(8):1406-19.

3. Tomasi C, Wennström JL, Berglundh T. Longevity of teeth and implants-a systematic review. J Oral Rehabil. 2008;35(Suppl1):23-32.

4. Pietrokovski J, Starinsky R, Arensburg B, Kaffe I. Morphologic characteristics of bony edentulous jaws. J Prosthodont. 2007;16:141-7.

5. Misawa M, Lindhe J, Araújo MG. The alveolar process following single-tooth extraction: a study of maxillary incisor and premolar sites in man. Clin Oral Implants Res. 2016;27(7):884-9.

6. Esposito M, Grusovin MG, Felice P, Karatzopoulos G, Worthington HV, Coulthard P. Interventions for replacing missing teeth: horizontal and vertical bone augmentation techniques for dental implant treatment. Cochrane Database Syst Rev. 2009;4, CD003607.

7. Calori GM, Mazza E, Colombo M, Ripamonti C. The use of bone-graft substitutes in large bone defects: any specific needs? Injury. 2011;42 Suppl 2:S56-63.

8. Zizzari VL, Zara S, Tetè G, Vinci R, Gherlone E, Cataldi A. Biologic and clinical aspects of integration of different bone substitutes in oral surgery: a literature review. Oral Surg Oral Med Oral Pathol Oral Radiol. 2016;122(4):392-402

9. Caplan Al. Adult mesenchymal stem cells for tissue engineering versus regenerative medicine. J Cell Physiol. 2007;213(2):341-7.

10. Salgado AJ, Oliveira JM, Martins A, Teixeira FG, Silva NA, Neves NM, Sousa N, Reis RL. Tissue engineering and regenerative medicine: past, present, and future. Int Rev Neurobiol. 2013;108:1-33.

11. D'Aquino R, De Rosa A, Laino G, Caruso F, Guida L, Rullo R, Checchi V, Laino L, Tirino V, Papaccio G. Human dental pulp stem cells: from biology to clinical applications. J Exp Zool B Mol Dev Evol. 2009;312B(5):408-15.

12. Liu J, Yu F, Sun Y, Jiang B, Zhang W, Yang J, Xu GT, Liang A, Liu S. Concise reviews: characteristics and potential applications of human dental tissuederived mesenchymal stem cells. Stem Cells. 2015:33(3):627-38.

13. Nuti N, Corallo C, Chan BM, Ferrari M, Gerami-Naini B. Multipotent differentiation of human dental pulp stem cells: a literature review. Stem Cell Rev. 2016;12(5):511-23.

14. Walker MR, Patel KK, Stappenbeck TS. The stem cell niche. J Pathol. 2009; 217(2):169-80.
15. Hall PA, Watt FM. Stem cells: the generation and maintenance of cellular diversity. Development. 1989;106(4):619-33.

16. Ullah I, Subbarao RB, Rho GJ. Human mesenchymal stem cells_current trends and future prospective. Biosci Rep. 2015;35(2):pii e00191.

17. Zhao H, Chai Y. Stem cells in teeth and craniofacial bones. J Dent Res. 2015; 94(11):1495-501.

18. Gronthos S, Mankani M, Brahim J, Robey PG, Shi S. Postnatal human dental pulp stem cells (DPSCs) in vitro and in vivo. Proc Natl Acad Sci U S A. 2000; 97:13625-30.

19. Miura M, Gronthos S, Zhao M, Lu B, Fisher LW, Robey PG, et al. SHED: stem cells from human exfoliated deciduous teeth. Proc Natl Acad Sci U S A. 2003;100:5807-12.

20. Seo BM, Miura M, Gronthos S, Bartold PM, Batouli S, Brahim J, Young M, Robey PG, Wang CY, Shi S. Investigation of multipotent postnatal stem cells from human periodontal ligament. Lancet. 2004;364:149-55.

21. Sonoyama W, Liu Y, Yamaza T, Tuan RS, Wang S, Shi S, et al. Characterization of the apical papilla and its residing stem cells from human immature permanent teeth: a pilot study. J Endod. 2008;34:166-71.

22. Zhang Q, Shi S, Liu Y, Uyanne J, Shi Y, Shi S, et al. Mesenchymal stem cells derived from human gingiva are capable of immunomodulatory functions and ameliorate inflammation-related tissue destruction in experimental colitis. J Immunol. 2009;183:7787-98.

23. Huang AH, Chen YK, Chan AW, Shieh TY, Lin LM. Isolation and characterization of human dental pulp stem/stromal cells from nonextracted crown-fractured teeth requiring root canal therapy. J Endod. 2009;35(5):673-81.

24. Rajendran R, Gopal S, Masood H, Vivek P, Deb K. Regenerative potential of dental pulp mesenchymal stem cells harvested from high caries patient's teeth. J Stem Cells. 2013;8(1):25-41.

25. Wang Z, Pan J, Wright JT, Bencharit S, Zhang S, Everett ET, Teixeira FB, Preisser JS. Putative stem cells in human dental pulp with irreversible pulpitis: an exploratory study. J Endod. 2010;36(5):820-5.

26. Sun $\mathrm{HH}$, Chen B, Zhu QL, Kong H, Li OH, Gao LN, Xiao M, Chen FM, Yu Q. Investigation of dental pulp stem cells isolated from discarded human teeth extracted due to aggressive periodontitis. Biomaterials. 2014;35(35):9459-72.

27. Alge DL, Zhou D, Adams LL, Wyss BK, Shadday MD, Woods EJ, Gabriel Chu TM, Goebel WS. Donor-matched comparison of dental pulp stem cells and bone marrow-derived mesenchymal stem cells in a rat model. J Tissue Eng Regen Med. 2010:4(1):73-81.

28. Kawashima N. Characterisation of dental pulp stem cells: a new horizon for tissue regeneration? Arch Oral Biol. 2012:57(11):1439-58.

29. Yu J, Wang Y, Deng Z, Tang L, Li Y, Shi J, Jin Y. Odontogenic capability: bone marrow stromal stem cells versus dental pulp stem cells. Biol Cell. 2007:99(8):465-74

30. Li N, Liu N, Zhou J, Tang L, Ding B, Duan Y, Jin Y. Inflammatory environment induces gingival tissue-specific mesenchymal stem cells to differentiate towards a pro-fibrotic phenotype. Biol Cell. 2013;105(6):261-75.

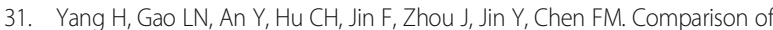
mesenchymal stem cells derived from gingival tissue and periodontal ligament in different incubation conditions. Biomaterials. 2013:34(29):7033-47.

32. Hess K, Ushmorov A, Fiedler J, Brenner RE, Wirth T. TNFalpha promotes osteogenic differentiation of human mesenchymal stem cells by triggering the NF-kappaB signaling pathway. Bone. 2009;45:367-76.

33. Hronik-Tupaj M, Rice WL, Cronin-Golomb M, Kaplan DL, Georgakoudi I. Osteoblastic differentiation and stress response of human mesenchymal stem cells exposed to alternating current electric fields. Biomed Eng Online. 2011;10:9

34. Patil $\mathrm{S}$, et al. A comprehensive review on the role of various materials in the osteogenic differentiation of mesenchymal stem cells with a special focus on the association of heat shock proteins and nanoparticles. Cells Tissues Organs. 2014;199:81-102.

35. Chen, et al. Extracellular heat shock protein 70 promotes osteogenesis of human mesenchymal stem cells through activation of the ERK signaling pathway. FEBS Lett. 2015;589:4088-96.

36. Chen $\mathrm{L}$, et al. Inhibiting actin depolymerization enhances osteoblast differentiation and bone formation in human stromal stem cells. Stem Cell Res. 2015;15:281-9.

37. Livak KJ, Schmittgen TD. Analysis of relative gene expression data using real-time quantitative $P C R$ and the 2- $\Delta \Delta$ Ct method. Methods. 2001:25: 402-8.

38. Gorska R, Gregorek H, Kowalski J, Laskus-Perendyk A, Syczewska M, Madalinski K. Relationship between clinical parameters and cytokine profiles 
in inflamed gingival tissue and serum samples from patients with chronic periodontitis. J Clin Periodontol. 2003;30(12):1046-52.

39. Yang $X$, Zhang S, Pang X, Fan M. Pro-inflammatory cytokines induce odontogenic differentiation of dental pulp-derived stem cells. J Cell Biochem. 2012;113(2):669-77.

40. Palmqvist $P$, Lundberg $P$, Lundgren I, Hänström L, Lerner UH. IL-1 beta and TNF-a regulate IL-6-type cytokines in gingival fibroblasts. J Dent Res. 2008; 87:558-63.

41. Feng X, Feng G, Xing J, Shen B, Li L, Tan W, Xu Y, Liu S, Liu H, Jiang J, Wu H, Tao T, Gu Z. TNF-a triggers osteogenic differentiation of human dental pulp stem cells via the NF-KB signalling pathway. Cell Biol Int. 2013;37(12):1267-75.

42. Carrero R, Cerrada I, Lledó E, Dopazo J, García-García F, Rubio MP, Trigueros C, Dorronsoro A, Ruiz-Sauri A, Montero JA, Sepúlveda P. IL1ß induces mesenchymal stem cells migration and leucocyte chemotaxis through NFkB. Stem Cell Rev. 2012:8(3):905-16.

43. Cuerquis J, Romieu-Mourez R, François M, Routy JP, Young YK, Zhao J, Eliopoulos N. Human mesenchymal stromal cells transiently increase cytokine production by activated T cells before suppressing T-cell proliferation: effect of interferon- $y$ and tumor necrosis factor-a stimulation. Cytotherapy. 2014;16(2):191-202.

44. Fu X, Xiao J, Wei Y, Li S, Liu Y, Yin J, Sun K, Sun H, Wang H, Zhang Z, Zhang BT, Sheng C, Wang H, Ping H. Combination of inflammation-related cytokines promotes long-term muscle stem cell expansion. Cell Res. 2015;25:655-73.

45. Ennis WJ, Sui A, Bartholomew A. Stem cells and healing: impact on inflammation. Adv Wound Care (New Rochelle). 2013;2(7):369-78.

46. McBeath R, Pirone DM, Nelson CM, Bhadriraju K, Chen CS. Cell shape, cytoskeletal tension, and RhoA regulate stem cell lineage commitment. Dev Cell. 2004;6(4):483-95.

47. Feng G, Zheng K, Song D, Xu K, Huang D, Zhang Y, Cao P, Shen S, Zhang J, Feng X, Zhang D. SIRT1 was involved in TNF-a-promoted osteogenic differentiation of human DPSCs through Wnt/B-catenin signal. In Vitro Cell Dev Biol Anim. 2016;52(10):1001-11.

48. Yourek G, Hussain MA, Mao JJ. Cytoskeletal changes of mesenchymal stem cells during differentiation. ASAIO J. 2007;53(2):219-28.

49. Treiser MD, Yang EH, Gordonov S, Cohen DM, Androulakis IP, Kohn J, Chen CS, Moghe PV. Cytoskeleton-based forecasting of stem cell lineage fates. Proc Natl Acad Sci U S A. 2010;107(2):610-5.

50. Gao J, Shanmin F, Zeng Z, Li F, Niu Q, Jing D, Feng X. Cyclic stretch promotes osteogenesis-related gene expression in osteoblast-like cells through a cofilin-associated mechanism. Mol Med Rep. 2016;14(1):218-24.

51. Sen B, Xie Z, Uzer G, Thompson WR, Styner M, Wu X, Rubin J. Intranuclear actin regulates osteogenesis. Stem Cells. 2015;33(10):3065-76.

52. Ghosh M, Song X, Mouneimne G, Sidani M, Lawrence DS, Condeelis JS. Cofilin promotes actin polymerization and defines the direction of cell motility. Science. 2004;304(5671):743-6.

53. Kim HR, Graceffa P, Ferron F, Gallant C, Boczkowska M, Dominguez R, Morgan KG. Actin polymerization in differentiated vascular smooth muscle cells requires vasodilator-stimulated phosphoprotein. Am J Physiol Cell Physiol. 2010;298(3):C559-71.

54. Yun SP, Ryu JM, Jang MW, Han HJ. Interaction of profilin-1 and F-actin via a $\beta$-arrestin-1/JNK signaling pathway involved in prostaglandin E(2)-induced human mesenchymal stem cells migration and proliferation. J Cell Physiol. 2011;226(2):559-71.

55. Miyajima D, Hayata T, Suzuki T, Hemmi $H$, Nakamoto T, Notomi T, Amagasa T, Böttcher RT, Costell M, Fässler R, Ezura Y, Noda M. Profilin1 regulates sternum development and endochondral bone formation. J Biol Chem. 2012;287(40):33545-53

56. Campos SB, Ashworth SL, Wean S, Hosford M, Sandoval RM, Hallett MA, Atkinson SJ, Molitoris BA. Cytokine-induced F-actin reorganization in endothelial cells involves RhoA activation. Am J Physiol Renal Physiol. 2009; 296(3):F487-95.

57. Taiyab A, Rao CM. HSP90 modulates actin dynamics: Inhibition of HSP90 leads to decreased cell motility and impairs invasion. Biochim Biophys Acta. 2011;1813(1):213-21.

\section{Submit your next manuscript to BioMed Central and we will help you at every step:}

- We accept pre-submission inquiries

- Our selector tool helps you to find the most relevant journal

- We provide round the clock customer support

- Convenient online submission

- Thorough peer review

- Inclusion in PubMed and all major indexing services

- Maximum visibility for your research

Submit your manuscript at www.biomedcentral.com/submit

C) Biomed Central 